\title{
Grzegorz Karasiewicz
}

Faculty of Management, University of Warsaw

\author{
Martyna Kowalczuk \\ Zenith Optimedia Group
}

\section{Effect of Celebrity Endorsement in Advertising Activities by Product Type}

\begin{abstract}
This article seeks to answer two related questions: are celebrity endorsements more likely to be result in a higher evaluation of the product being advertised than use of an anonymous individual (e.g. a typical consumer); and, if present, do these positive effects vary by product category? To answer these two questions research was conducted on a 237 student sample employing a quasi-experiment consisting of four groups (two product categories and two types of endorsers) using data collected through an online survey. The results indicate that celebrity endorsements do have a positive impact on the evaluation of durable goods, but do not affect the evaluation of frequently purchased products. This finding largely confirms the assumptions of the match-up model, the meaning transfer model, and the ELM model.
\end{abstract}

Keywords: celebrity endorsement, endorser, advertising, brand.

JEL: M37

\section{Introduction}

The use of celebrity endorsements in advertising first appeared in the 19th century, and was further developed in the 20th century with the emergence of new advertising media: the radio (1930s); television (1950s); and the Internet (1990s) [Erdogan, 1999, 
p. 292; Racula, 2012, p. 75]. This advertising technique is now one of the most ways to reach consumers. [Agrawal, Kamakura, 1995, p. 58; Ding et al., 2011, p. 148]. It is estimated that more than $25 \%$ of advertising campaigns in the USA used celebrities [Erdogan, 1999, p. 292; Erdogan et al., 2001, p. 39], and about 10\% of advertising budgets were allocated to paying celebrities [Agrawal, Kamakura, 1995, p. 58].

According to definition, "a celebrity endorser is an individual who is known by the public for his or her achievements in areas other than that of the product class endorsed" [Friedman, Friedman, 1979, p. 63]. The use of celebrities in advertising: (1) attracts attention of the surrounding world (consumers, traders); (2) strengthens the advertising message; (3) refines brand image, giving it a new and better meaning; (4) is an opportunity to enter other geographical markets through the use of celebrities globally. [Erdogan, 1999, pp. 295-296; Racula, 2012, pp. 77-78; Abdussalam, 2014, pp. 80-82]

The use of a celebrity's image does not, however, guarantee success; as with every most managerial decisions, this advertising technique poses risks, including: (1) a mismatch between the celebrity and the product advertised; (2) brands being obscured by an overwhelming celebrity; (3) the overuse of a particular celebrity by too many brands, leading to conflicting advertising messages; (4) that a celebrity working under a long-term advertising behaves badly, drawing negative publicity that undermines brand reputation; (5) a decreased interest in the brand when a celebrity loses importance or the public's attention; (6) the general impact of significantly increased advertising campaign costs [Erdogan, 1999, pp. 295-296; Racula, 2012, pp. 77-78; Abdussalam, 2014, pp. 80-82].

Employing a pros and cons analysis of celebrity endorsements, a publication aims at answering the following questions: do celebrity endorsements achieve better results (i.e., product evaluation) than the use of anonymous individuals (e.g., typical consumers) and do these effects vary by product category?

\section{Theoretical Models}

The literature dealing with celebrity advertising impacts identifies five models that describe celebrity endorsement. The purpose of each is to clarify the relationship between the product (brand), celebrity, and process by which a celebrity's characteristics are transferred to the brand (endorsement process) [McCracken, 1989, pp. 310-312; Ergodan 1999, pp. 297; Mittelstaedt et al.2000, pp. 56-57; Hung et al., 310-312; Ergodan, 1999, pp. 297; Mittelstaedt et al., 2000, pp. 56-57; Hung et al., 2011, pp. 610; Racula, 2012, pp. 76-77; Carrilant et al., 2013, pp. 16-17; Hung, 2014, pp. 155-158]. These five models are:

1. The source model - based on the assumption that recipients will believe and accept an advertising message if the celebrity is trustworthy (defined as the perceived willingness of the source to make valid assertions), is an expert (defined as the perceived ability of the source to make valid assertions) and/or is attractive (a celebrity's popularity, physical 
attractiveness). This model is based on research carried out in that social psychology field that defines two source model elements - trustworthiness and expertness [Hovland, Weiss, 1951, pp. 635-650]. The third component of this model, i.e., attractiveness, which also relies on theories derived from social psychology [McGuire, 1985, p. 264], was discovered and empirically verified by Weiner and Mowen [1986, pp. 306-310]. The source model assumes that using a celebrity with certain characteristics (trustworthiness, expertness and/or attractiveness) in advertising activities relating to any product category will bring positive effects.

2. The match-up model (the Product Match-up Hypothesis / celebrity-brand congruence model) is based on the hypothesis [Kamins, 1990, pp. 5-6] that the effects of using a celebrity in marketing communications depends on the degree of perceived fit between the brand (product name, symbol, image, benefits and attributes) and image of the celebrity. This model is consistent with the social adaptation theory [Kahle and Homer, 1985, pp. 954-955], which postulates that adaptive significance of information determines its impact on recipients, thus contributing to positive effects of advertising activities. Celebrity choice is based on the assumption that not every celebrity will effectively advertise every brand in any product category. This accentuates the risks of (1) too many brands using the same celebrity and (12) his or her potential for controversial behavior in the future. The model's limitation is its inability to define and measure celebrity characteristics that are important for individual product categories and brands.

3. The meaning transfer model was developed by McCracken, and consists of three stages showing the transfer of characteristics/meanings [1989, pp. 313-318]. At the first stage - "culture" - a celebrity is defined by all characteristics that correspond to his or her image in the media through work performed, statements, roles played, etc. At the second stage - "endorsement" - various associations with the celebrity are transferred to the product (brand) advertised by him or her. The key issue at this stage is to determine the symbolic properties of the brand to be strengthened or created through advertising activities, and to then select a celebrity who is consistent with desired symbolic properties. At the third stage - "consumption" - the desired meanings linked to a celebrity are passed on from the product (brand) to the recipient (consumer). In this situation, the process of consumption or use is given a broader context as the consumer becomes a part of a larger whole, gains self-appreciation and strengthens his or her own self-image through the transfer of such meanings. The choice of celebrity to advertise a brand should take into account the relationship of the celebrity's image with the desired image and perceived benefits and attributes of the brand. This model is a significant extension of the match-up model because it emphasizes not only the celebrity-brand match-up but also the choice of meanings to be transferred from the celebrity to the advertised brand. An elaboration of this approach is the model proposed by Misra and Beatty [1990, pp. 159-173], who imply 
that meanings are not transferred in one direction only, i.e., from the celebrity to the brand, but also from the brand to the celebrity. This is particularly pertinent when a celebrity becomes the face of the brand. Necessary conditions include long-term cooperation of the celebrity with the company (brand) and application of the exclusivity rule (a celebrity advertising one brand only).

4. The Elaboration Likelihood Model (ELM) is based on the assumption [Petty, Cacioppo, 1980, pp. 75-79; Hung, 2014, pp. 156-158] that recipients (consumers) respond to an advertising message (including use of a celebrity) in various ways depending on situational factors (resulting from the importance of a product category, and thus the type of purchasing decisions, medium, message reception time, etc.). On this basis, two situations related to an advertising message reception may be distinguished: high and low involvement. In the first case, the reception of an advertising message is elaborate and systematic, which can lead to a permanent change in the recipient's attitudes. Because recipients pay attention to the arguments contained in the advertising message and then the celebrity should, first and foremost, be an expert in a given field. In the second situation, the reception of an advertising message is peripheral and heuristic, which weakens its influence on attitudes. Recipients with low involvement focus on superficial characteristics of the message. Thus, a key element is that the celebrity be attractive.

5. The Dual entertainment path model has, as a starting point, the following entertainment [Valkenburg and Voort, 1994, pp. 334-337; Vorderer et al., 2004, pp. 393-403] and transportation theories [Green et al., 2004, pp. 312-324; Green and Brock, 2000, pp. 701-702]. Unlike the ELM model, which is based on a cognitive approach, this model focuses on the recipient's experience [Hung, 2014, pp. 155]. Similarly to the ELM model, two situations are distinguished: the high and low involvement of the recipient. In the first situation, aspirational motives are the key: the consumer wants to be the same as the celebrity and imitate his or her lifestyle. A strong parasocial bond with the celebrity then appears, which is determined by emotional investment. The second situation is connected with playful motives. This means a weaker parasocial bond with the celebrity. The key for building the recipient's attention is avoiding boredom and creating the fiction of escaping from real life through imagination and dreams [Hung, 2014, pp. 156-159].

\section{Previous Studies' Overview}

Empirical studies using these five celebrity endorsement models are presented in Table 1. The largest group of studies applied the match-up model. Determining communication effects of celebrity endorsement (attitude towards the brand, purchase intention, 
degree of brand awareness, degree to which an advertisement is remembered, etc.) was the predominant purpose. Relatively few studies refer to financial results, including the company's value for its owners; these include: Agrawal and Kamakura [1995, pp. 56-60], Ding, Malchanov, Stork [2010, pp. 147-163]. Most studies are based on a research design involving experiments or quasi-experiments carried out in two or more groups. Examples include one of the first studies on celebrity endorsement effects conducted by Friedman, Friedman [1979, pp. 63-71] and another one - the most frequently cited study by Kamins [1990, pp. 4-19]. Polish studies have not, however, been conducted in an experiment form [Woźniczka, 2011, pp.14-22].

Friedman and Friedman [1979, pp. 63-71] analysed three products: biscuits, a vacuum cleaner, and imitation jewellery. They were promoted through advertisements using different messaging sources: a housewife, an expert, and a celebrity. In addition, a "placebo" advertisement was introduced without any message source (endorser). The experiment design comprised twelve groups. For each group, an identically laid out advertisement was prepared, and all products had the same name - "Majestik". The study sample included housewives living in Brooklyn. With respect to each group, 30 randomly selected respondents were interviewed. The total study sample consisted of 360 people [pp. 65-66]. The study results showed that different products should be advertised by different types of endorsers for the message to reach recipients in accordance with the intended purpose. Imitation jewellery of dubious quality was rated as a more attractive product when advertised by a celebrity, but less highly evaluated when presented by other endorsers - a housewife and an expert (in the jewellery industry) [pp. 66-70].

The second study, carried out by Kamins [1990, pp. 4-19], concerned advertisements of two products: a computer and a luxury car, presented by two well-known actors - one belonging to the "attractive" and the other to the "less attractive" categories. The experiment design consisted of four groups. The study sample included students, each of whom was randomly assigned to one of the groups, and the total study sample size was 89 respondents [pp. 7-9]. The study results indicate that the "attractive" actor fits a luxury car advertisement better. Respondents who were presented with the luxury car advertisement featuring the "attractive" actor evaluated the actor himself as more trustworthy and the advertised car as being of better quality than in the luxury car advertisement featuring the "less attractive" actor. The opposite effect was observed for the personal computer, which was better evaluated in the advertisement featuring the "less attractive" actor, who himself was more trustworthy according to respondents [pp. 9-10].

Research by Woźniczka [2011, pp. 14-22] was also carried out on a student sample. The total sample size was 145 people. The research involved the presentation of single shots of $10 \mathrm{TV}$ commercials to respondents. Each commercial referred to a different consumer product. Five commercials used "ordinary people" and other five "celebrities". For each commercial, respondents were to answer questions relating to commercial recognition, brand recognition, attitude towards the commercial, attitude towards the spokesperson, 
and the impact of the commercial on their future purchase intentions [pp. 17-19]. The results of this research indicate that celebrity use does not lead to clear differences in communication effects, with the exception of attitudes towards the advertisement and the persons appearing in it [pp. 19-22].

\section{TABLE 1. Overview of previous studies}

\begin{tabular}{|c|c|c|}
\hline Study & Model & Conclusions \\
\hline $\begin{array}{l}\text { Friedman, Friedman, } \\
1979\end{array}$ & $\begin{array}{l}\text { Source } \\
\text { Match-up }\end{array}$ & $\begin{array}{l}\text { The celebrity was more effective than the expert or typical- } \\
\text { consumer endorser in sustaining recall of the advertisement } \\
\text { and the brand name of the product, regardless of product type. } \\
\text { Attitude towards brand and intention to purchase depended on } \\
\text { the type of products. Celebrity endorsers were appropriate where } \\
\text { products purchased involved high social and psychological risk. }\end{array}$ \\
\hline $\begin{array}{l}\text { Petty, Cacioppo, } \\
\text { Goldman, } 1981\end{array}$ & ELM & $\begin{array}{l}\text { Found that the quality of arguments contained in a message } \\
\text { has a greater impact on persuasion under high involvement } \\
\text { conditions, whereas under low involvement conditions } \\
\text { peripheral cues - source attractiveness, credibility - have } \\
\text { a greater impact on persuasion. }\end{array}$ \\
\hline $\begin{array}{l}\text { Petty, Cacioppo, } \\
\text { Schumann, } 1983\end{array}$ & ELM & $\begin{array}{l}\text { The manipulation of argument quality had a greater impact } \\
\text { on brand attitudes under high than low involvement, but the } \\
\text { manipulation of the product endorser had a greater impact under } \\
\text { low than high involvement. }\end{array}$ \\
\hline Khale, Homer, 1985 & Source & $\begin{array}{l}\text { Attitudes and purchase intentions changed due to celebrity } \\
\text { source attractiveness, consistent with social adaptation theory }\end{array}$ \\
\hline $\begin{array}{l}\text { Speck, Schumann, } \\
\text { Thompson, } 1988\end{array}$ & Source & $\begin{array}{l}\text { Found that expert celebrities produced a higher recall of product } \\
\text { information than non-expert celebrities; but the difference was } \\
\text { not statistically significant. }\end{array}$ \\
\hline $\begin{array}{l}\text { Kamins, Brand, } \\
\text { Hoeke, Moe, } 1989\end{array}$ & Source & $\begin{array}{l}\text { Indicated the effectiveness of a two-sided, as opposed to one- } \\
\text { sided, celebrity spokesperson appeal. }\end{array}$ \\
\hline Kamins, 1990 & Match-up & $\begin{array}{l}\text { Found that physically attractive celebrities enhance credibility } \\
\text { and attitudes for attractive products. The physical attractiveness } \\
\text { of a celebrity endorser may only enhance both product-ad-based } \\
\text { evaluations if the brand's characteristics "match-up" with the } \\
\text { image conveyed by the celebrity. }\end{array}$ \\
\hline Misra, Beatty, 1990 & Match-up & $\begin{array}{l}\text { Found that advertising recall, then transfer affects from } \\
\text { spokesperson to brand, and affect toward the brand are } \\
\text { significantly higher when the spokesperson is congruent with } \\
\text { brand. }\end{array}$ \\
\hline $\begin{array}{l}\text { Langmeyer, Walker, } \\
1991\end{array}$ & $\begin{array}{l}\text { Meaning } \\
\text { transfer }\end{array}$ & $\begin{array}{l}\text { Found that celebrities embody various meanings that are passed } \\
\text { on to brands with endorsements. }\end{array}$ \\
\hline Ohanian, 1991 & Source & $\begin{array}{l}\text { Perceived expertise of the celebrities was a significant factor } \\
\text { explaining the respondents' intention to purchase the product. } \\
\text { Attractiveness and trustworthiness of the celebrities had an } \\
\text { insignificant impact on the intent to purchase the product. }\end{array}$ \\
\hline
\end{tabular}




\begin{tabular}{|c|c|c|}
\hline Study & Model & Conclusions \\
\hline Kamins, Gupta, 1994 & Match-up & $\begin{array}{l}\text { Found that the higher level match-up between spokesperson and } \\
\text { product resulted in increased believability, attractiveness of the } \\
\text { spokesperson, and positive attitudes toward the product. }\end{array}$ \\
\hline Lynch, Schuler, 1994 & Match-up & $\begin{array}{l}\text { Found that the congruence in advertisements between } \\
\text { spokesperson characteristics and product attributes is related } \\
\text { to observed variations in source credibility, product evaluations, } \\
\text { perceived product gender, and other measures of advertising and } \\
\text { communication effectiveness. }\end{array}$ \\
\hline $\begin{array}{l}\text { Agrwala, Kamura, } \\
1995\end{array}$ & - & $\begin{array}{l}\text { Positive impact of announcing celebrity endorsements on stock } \\
\text { returns. }\end{array}$ \\
\hline $\begin{array}{l}\text { O’Mahony, } \\
\text { Meenaghan, } \\
\text { 1997/1998 }\end{array}$ & Match-up & $\begin{array}{l}\text { The study confirmed that consumers expect congruence between } \\
\text { the perceived image of the celebrity endorser and product } \\
\text { types. Celebrities must possess expertise in product categories } \\
\text { consistent with their public image. }\end{array}$ \\
\hline Till, Busler, 1998 & $\begin{array}{l}\text { Match-up } \\
\text { Source }\end{array}$ & $\begin{array}{l}\text { Found that expertise is more important than physical } \\
\text { attractiveness for matching a brand with an appropriate endorser. }\end{array}$ \\
\hline $\begin{array}{l}\text { Mittelstaedt, Riesz, } \\
\text { Burns, } 2000\end{array}$ & Match-up & $\begin{array}{l}\text { Indicated that matches between endorsers and products, rather } \\
\text { than the nature of the products or the endorsers themselves, } \\
\text { affect the perceived effectiveness of endorsements. }\end{array}$ \\
\hline Till, Busler, 2000 & Match-up & $\begin{array}{l}\text { Found that the variables "fit" or "belongingness" are important } \\
\text { to understanding the match-up effects between celebrity and } \\
\text { brand. }\end{array}$ \\
\hline $\begin{array}{l}\text { Stafford, Stafford, Day, } \\
2002\end{array}$ & Match-up & $\begin{array}{l}\text { Found that the effectiveness of a celebrity will probably vary } \\
\text { on the basis of whether the service is utilitarian or hedonic. } \\
\text { Celebrities create trust and expertise for a hedonic service and } \\
\text { a positive affect for utilitarian services. }\end{array}$ \\
\hline Silvera, Austad, 2004 & $\begin{array}{l}\text { Match-up } \\
\text { Source }\end{array}$ & $\begin{array}{l}\text { The resulting model indicated that brand attitudes were } \\
\text { predicted by inferences about the linking of endorser's and the } \\
\text { product and attitudes toward the endorser. }\end{array}$ \\
\hline $\begin{array}{l}\text { Biswas, Biswas, Das, } \\
2006\end{array}$ & Source & $\begin{array}{l}\text { For high technology - oriented products, an endorsement by } \\
\text { a person perceived to be an expert for that product is more } \\
\text { effective in reducing perceived risk than an endorsement by } \\
\text { a celebrity or by a non-celebrity non-expert. }\end{array}$ \\
\hline Liu, Chen, Jiang,2007 & $\begin{array}{l}\text { Match-up } \\
\text { Source }\end{array}$ & $\begin{array}{l}\text { Found that the attractiveness of a spokesperson can affect } \\
\text { purchase intentions, particularly when match-up is low. }\end{array}$ \\
\hline Lee, Thorson, 2008 & Match-up & $\begin{array}{l}\text { Found that celebrity endorsements with moderate product } \\
\text { mismatch have more favorable purchase intentions than extreme } \\
\text { match or extreme mismatch, and that the effects of celebrity- } \\
\text { product congruence are more pronounced among participants } \\
\text { with higher product involvement than those with lower product } \\
\text { involvement. }\end{array}$ \\
\hline Lord, Putrevu, 2009 & $\begin{array}{l}\text { Source } \\
\text { ELM }\end{array}$ & $\begin{array}{l}\text { Found that the celebrity expertise and trustworthiness are } \\
\text { the primary determinants of informational motivation, while } \\
\text { attractiveness is the principal variable driving transformational } \\
\text { motivation. }\end{array}$ \\
\hline
\end{tabular}




\begin{tabular}{|l|l|l|}
\hline \multicolumn{1}{|c|}{ Study } & \multicolumn{1}{|c|}{ Model } & \multicolumn{1}{c|}{ Conclusions } \\
\hline Wheeler, 2009 & $\begin{array}{l}\text { Match-up } \\
\text { ELM }\end{array}$ & $\begin{array}{l}\text { Found that a celebrity who is closely connected to a non-profit } \\
\text { organization through experience and proper fit will generate } \\
\text { greater source credibility than others; the source credibility } \\
\text { generated by the connected celebrity will directly affect the } \\
\text { intention to volunteer time and donate money; the ad subject } \\
\text { involvement plays a significant role in determining the level of } \\
\text { source credibility and intention. }\end{array}$ \\
\hline $\begin{array}{l}\text { Ding, Malchanov, } \\
\text { Stork, 2010 }\end{array}$ & $\begin{array}{l}\text { Announcing celebrity endorsements do not experience positive } \\
\text { abnormal returns (net discounted cash flow to be close to zero). } \\
\text { Positive impact of endorser on abnormal returns: group (e.g., } \\
\text { a soccer team), athlete, celebrity-brand congruence, multiplicity } \\
\text { (multiple celebrities to advertise brand/ company). }\end{array}$ \\
\hline $\begin{array}{l}\text { Spry, Pappu, Cornwell, } \\
\text { 2011 }\end{array}$ & Source & $\begin{array}{l}\text { Found that endorser credibility has an indirect impact on brand } \\
\text { equity when this relationship is mediated by brand credibility. } \\
\text { This mediating relationship was moderated by type of branding. }\end{array}$ \\
\hline Woźniczka, 2011 & Source & $\begin{array}{l}\text { Found that the celebrity endorsement creates a better ad } \\
\text { and brand attitude then typical consumer, and there was } \\
\text { no statistically significant difference between celebrity and } \\
\text { typical consumer in ad recognition, brand awareness and brand } \\
\text { purchase intention. }\end{array}$ \\
\hline Hung, 2014 & $\begin{array}{l}\text { Found links between entertainment motives (aspirational } \\
\text { and playful) and experiences (celebrity fantasy and emotional } \\
\text { investment) influence endorsed brand attitude. Fans are driven } \\
\text { by both aspirational and playful motives to engage in celebrity- } \\
\text {-induced entertainment experiences. Non-fans are driven } \\
\text { predominantly by a playful motive. }\end{array}$ \\
path & pual & \\
\hline
\end{tabular}

Source: own elaboration.

\section{Research Methodology}

The starting point for designing the research methodology was to define the research problem and hypotheses. The research problem was formulated as: determining the impact of a celebrity's image on evaluation of the advertised product. The research used a quasi-experimental method involving four groups. This solution is typical for research on celebrity endorsements in advertising.

Four advertisements were prepared for the experiment - they were not used in the real world and featured generic (non-branded) products. The advertisements were full page press ads. An actress (Alicja Bachleda-Curuś) and an unknown model were selected as endorsers. These two persons were of similar physical attractiveness, such that the celebrity effect could be separated from the influence of the attractiveness of the endorsers on respondent assessments. ${ }^{1}$ 
Two products were used during the study. The first - colorful watches - is a product often considered tacky. The study's intended purpose was to verify whether the presence of a celebrity can boost a product's prestige and increase the interest of the respondents, as indicated by Friedman and Friedman (effect for imitation jewelry) [1979, pp. 63-71]. The second featured product was fruit juice, an uncomplicated product frequently purchased without much thought. It does not reflect the status of the buyer, is inexpensive and consumed at home, similarly to the biscuits described by Friedman and Friedman [pp. 63-71].

The research employed four questionnaires that differed in terms of the advertisement being shown (a combination of two advertised products and two endorsers) and, depending on the product advertised, asked several different questions. In the questionnaire, information about the research being conducted was followed by a display of the advertisement to be watched by respondents and questions to be answered. The first version of the questionnaire referred to the following situations: one, a celebrity and a speciality good (Watches A); two, an attractive but unknown model and a speciality good (Watches B); three, a celebrity and a convenience good (Juice A), and four, an attractive but unknown model and a convenience good (Juice B). For watches, in both cases the advertising slogan "fashionable watches" was used. For juices, the slogan used was "delicious juice". The attractiveness of the source and the advertisements was measured on a 5-item Likert scale (strongly disagree, disagree, neither agree nor disagree, agree, strongly agree).

With regard to the problem so defined and the research design, three hypotheses were specified:

- H1: The celebrity will be evaluated as more attractive than the model.

- H2: The celebrity will be better evaluated as an endorser than the model (likeability, credibility, trust).

- H3: The celebrity will have a positive impact on product evaluation.

The research was conducted through an online survey among students of four higher education institutions in Warsaw, i.e. the University of Warsaw, the Warsaw University of Technology, the Warsaw School of Economics, and the University of Medicine. ${ }^{2}$ The research involved 256 respondents: 149 women and 107 men. The answers given by respondents who did not fully complete the questionnaire were not taken into account. In total, there were 14 such partially completed questionnaires. The numbers of people in each of the advertisement options were as follows:

- Watches A - 72 people (44 women and 28 men),

- Watches B - 72 people (43 women and 29 men),

- Beverages A - 57 people (32 women and 25 men),

- Beverages B - 55 people (30 women and 25 men).

Since the paper analyses the celebrity effect, questionnaire with a celebrity included a question intended to verify whether respondents recognised the celebrity appearing in the advertisement. People who responded that they did not recognise the endorser 
in the Watches A and Beverages A questionnaires were excluded from the research. Thus, final respondent numbers in the two groups with a celebrity were:

- Watches A - 62 people (40 women and 22 men) - 10 persons did not recognise the celebrity,

- Beverages A - 48 people (31 women and 17 men) - 9 persons did not recognise the celebrity.

The research was conducted in 2014. A link to the questionnaires was published in a social networking service on 04.04.2014 and the survey was closed on 13.04.2014. Respondents were randomly redirected to one of the four questionnaires. Hence, respondents were not aware of other questionnaire versions used in the research. The research sample consisted of students, to reduce the costs of the experiment. Use of a representative nationwide sample is much costlier (a randomized quota selection would require a sample size of approximately 1300 respondents). Student samples have therefore been used in international studies on celebrity endorsement in advertising. Moreover, the high homogeneity of such a sample fairly permits the study results to generally be extended to the larger student population even when a relatively small sample is used. Finally, use of a student sample facilitates the use of an online survey, which is very most cost-effective. That communication pathway is, however, still problematic for much of the remainder of Poland's population.

To statistically analyze the collected material, the Student's t-test was used for two populations with unknown standard deviations. Although use of the Student's t-test for the ordinal-scale analysis of assessments has sometimes been criticised. Norman [2010, pp. 625-632] indicates that the results mirror more sophisticated statistical tests that are theoretically more appropriate for such data.

\section{Results Analysis - Hypothesis 1}

In order to verify this assumption, the questionnaires included a question about the endorser's attractiveness. Figure 1 shows respondents' overall average evaluations of perceived celebrity and non-celebrity attractiveness referring to watches and juices. Cumulative results for both questionnaires are presented, by endorser.

A comparison of the average perceived attractiveness of the celebrity and non-celebrity is shown. This comparison indicates that the average rating of the celebrity's attractiveness was statistically significantly higher than the rating of a non-celebrity $(p=0.000)$. This effect was also observed among the respondents describing advertisement with "watches" $(p=0.000)$, but not among respondents describing advertisement with "juices" $(p=0.249)$. This suggests that the observed differences in attractiveness evaluation may actually result not exclusively from the celebrity's greater physical attractiveness, but from some qualities of the advertised products which, in combination with the celebrity characteristics, lead to a higher evaluation of her attractiveness. 
FIGURE 1. Perceived attractiveness of product endorsers in advertisements

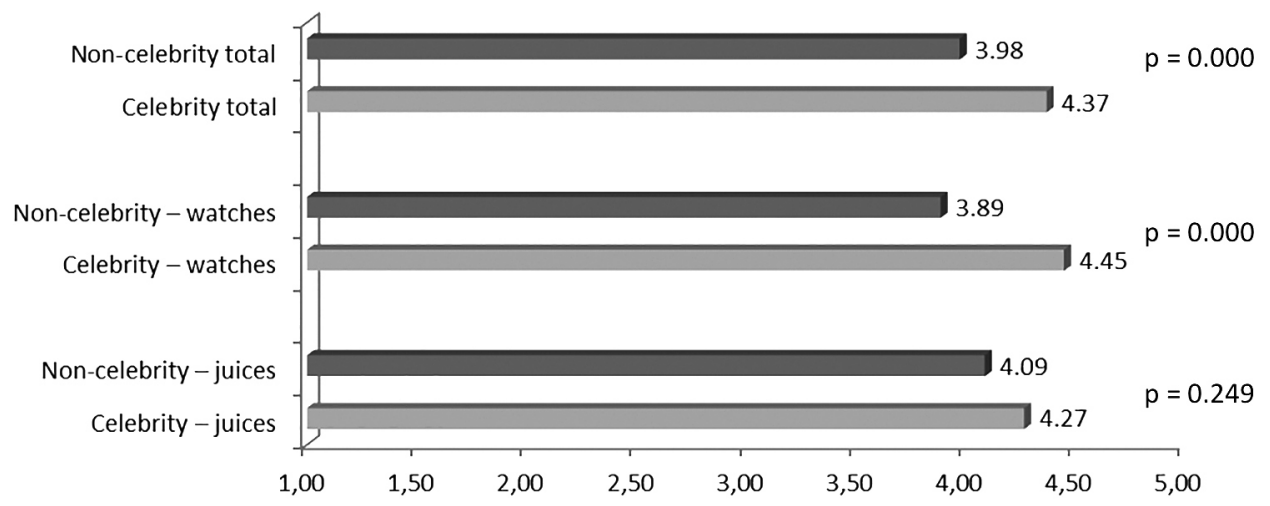

$\mathrm{p}<0.05$ means that the differences between the groups studied are statistically significant.

S ource: own elaboration.

\section{Results' Analysis - Hypothesis 2}

The next step in the analysis of the celebrity effect in advertising is to find out how product endorsers were evaluated and whether differences in these evaluations are statistically significant. For this purpose, the figures below compare total average ratings for the celebrity and non-celebrity (see Figure 2), in groups with watches (see Figure 3 ) and in groups with juices (see Figure 4).

\section{FIGURE 2. Total endorser ratings}

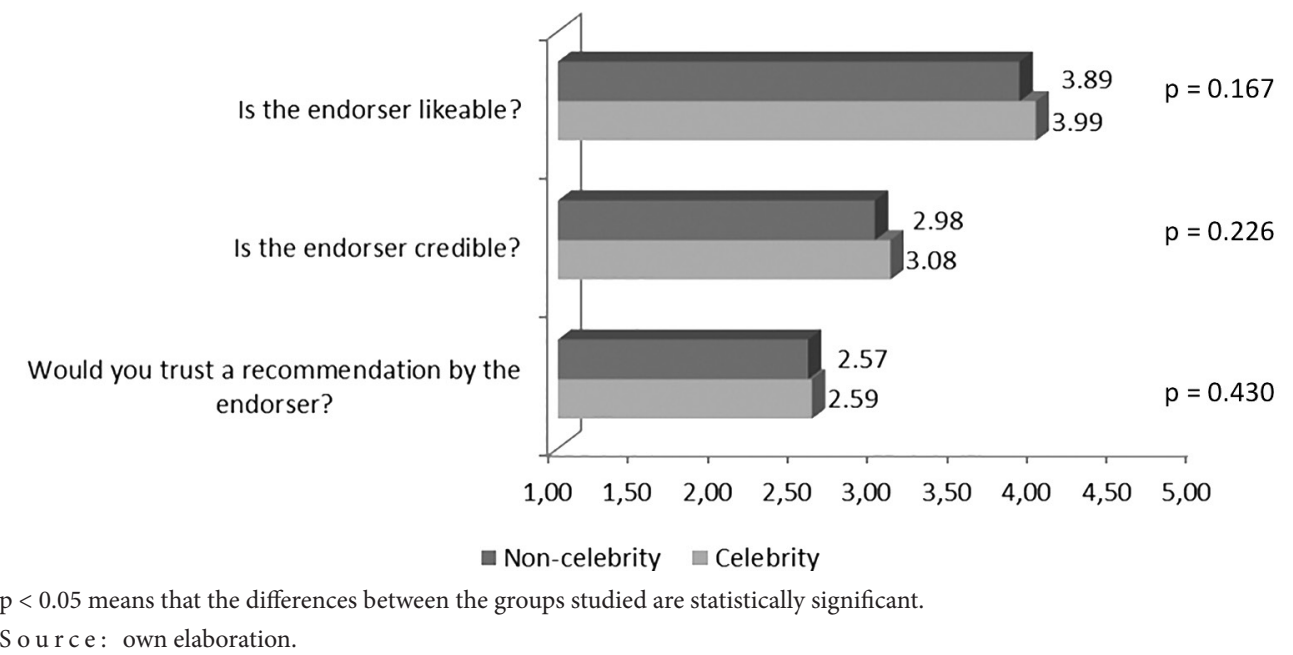




\section{FIGURE 3. Endorser ratings in watches questionnaires}

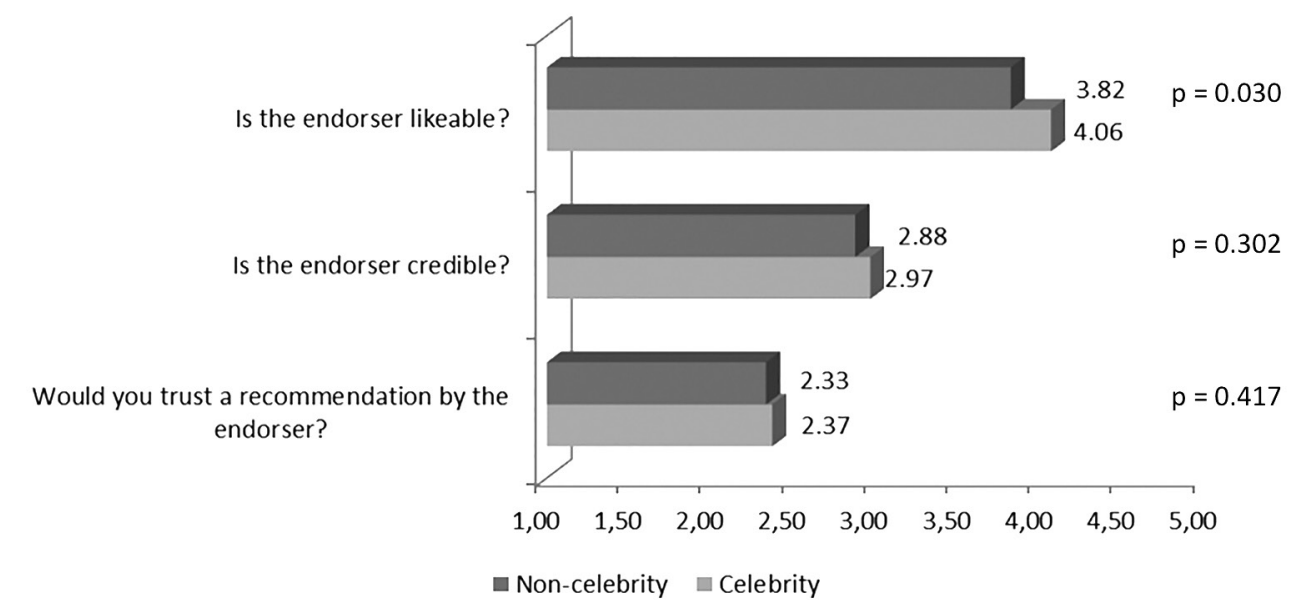

$p<0.05$ means that the differences between the groups studied are statistically significant.

Source: own elaboration.

\section{FIGURE 4. Endorser ratings in juices questionnaires}

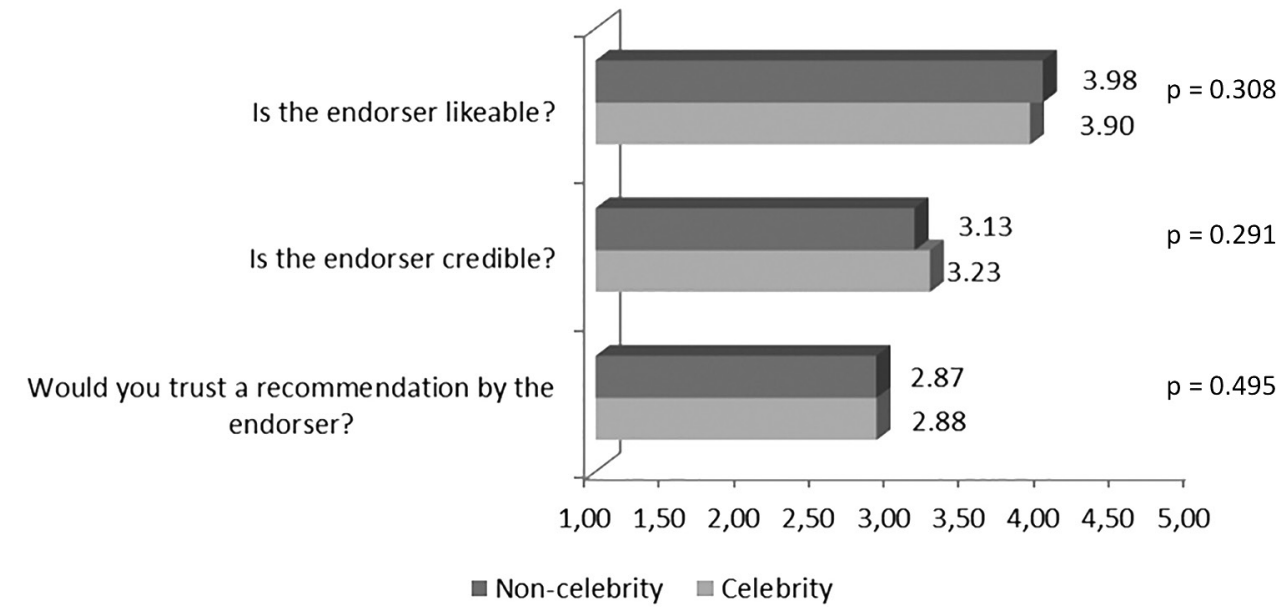

$\mathrm{p}<0.05$ means that the differences between the groups studied are statistically significant.

Source : own elaboration.

Hypothesis 2 assumed that the celebrity would be evaluated by respondents as more likeable, more credible and more trustworthy than the non-celebrity in both advertisements. The results obtained show that a statistically significant evaluation difference, with the celebrity rated higher in the watches survey regarding likeability (see Figure 3). 
In other cases there were no statistically significant differences between the ratings for the celebrity and non-celebrity, which undermines hypothesis H2. It should be recalled, however, that the celebrity was earlier considered as significantly more attractive in two of three analyzed comparisons (see Figure 1).

\section{Results' Analysis - Hypothesis 3}

Hypothesis 3 concerned the determination of the celebrity's impact on product evaluation in selected product categories. To carry out this analysis, five questions from the research questionnaires were used.

For the "watches" product category (see Figure 5), the results indicate that the assumed hypothesis held true in two dimensions. Watches evaluation is statistically significantly better in the questionnaire with the celebrity in the second question $(p=0.040)$, concerning willingness to use the product, and the third question, which refers to the product quality $(p=0.008)$. The higher rating in the third question may also indicate that the the celebrity adds prestige to the advertised product. The result obtained for the first question is close to the limit of statistical significance of $0.05(p=0.077)$. Therefore, celebrity endorsement in advertising may also contribute to a higher overall evaluation of the "appeal" of the product.

\section{FIGURE 5. Ratings for watches}

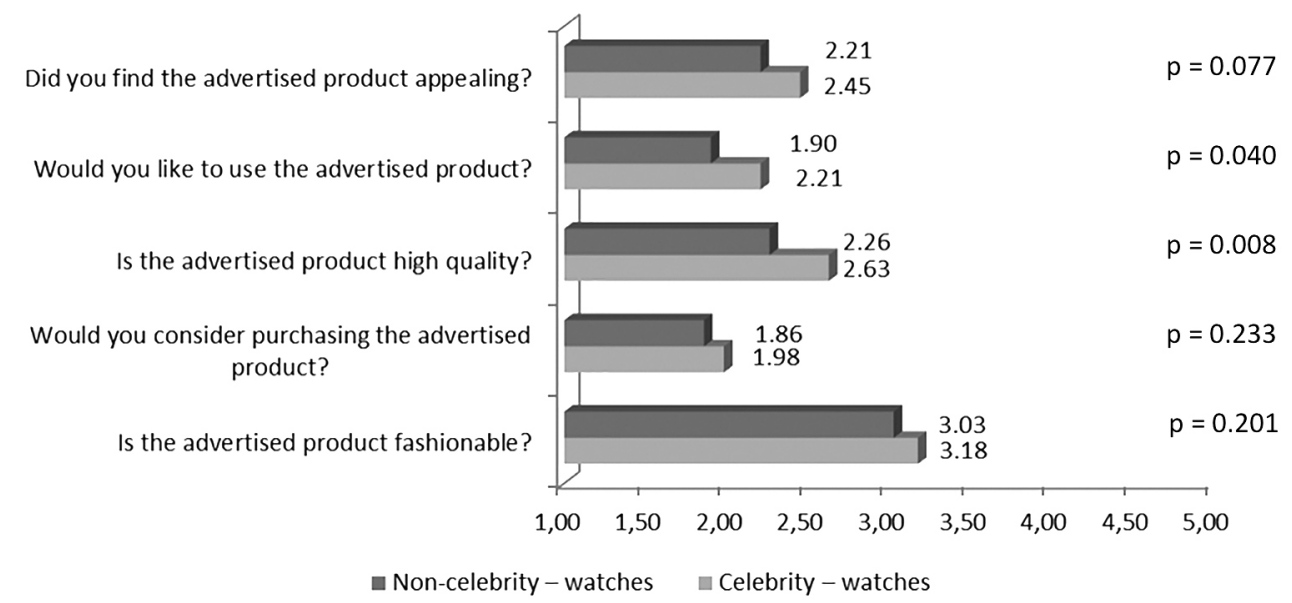

$\mathrm{p}<0.05$ means that the differences between the groups studied are statistically significant.

Source: own elaboration. 
In the fourth and fifth questions, differences in product ratings do not show significant statistical differences $(p=0.233$ and $p=0.201)$. Respondents considered the watches to be equally fashionable in both celebrity and non-celebrity endorsed advertisements, which may be due to the fact that the advertisement used the slogan "fashionable watches," giving equal ratings in both groups.

With respect to the "juices" product category, the research hypothesis that a celebrity affects product evaluation was rejected. No statistically significant differences between the groups studied were identified as regards all questions asked to evaluate the product (see Figure 6).

\section{FIGURE 6. Ratings for juices}

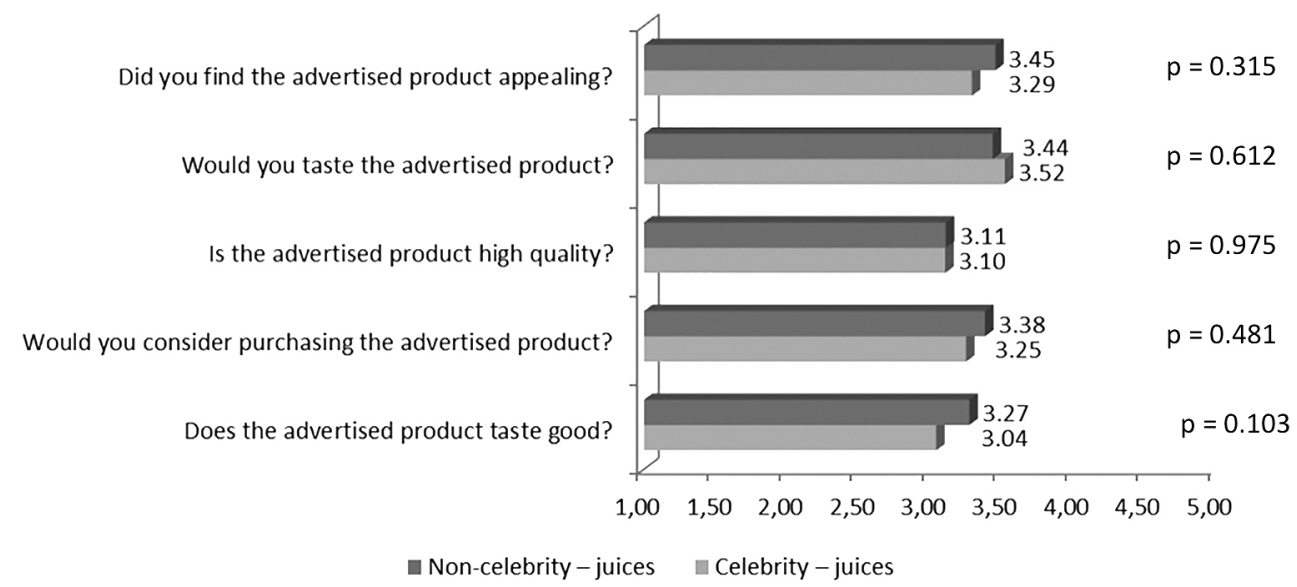

$\mathrm{p}<0.05$ means that the differences between the groups studied are statistically significant.

S ource: own elaboration.

\section{Conclusions and Managerial Implications}

1. Recipients of advertising consider celebrities to be of higher attractiveness than unknown models, depending on product category. In this study, the celebrity was perceived as more attractive in the case of the watches than juice. This allows us to formulate the first marketing implication: only in product categories where the physical attractiveness of an endorser is important (e.g., cosmetics) can that attractiveness be transferred onto the brand image and strengthen the brand's key attributes or perceived benefits. This finding is in accordance with the meaning transfer model by McCracken [1989, pp. 310-321] (celebrity endorsement in advertising can bring 
better communication results than the use of ordinary persons, experts or anonymous models), and with the research of Kamins [1990, pp. 1-19], who concluded that physical attractiveness of the communication source is significant for product categories associated with this characteristic.

2. Higher attractiveness of an endorser (in this study, the celebrity) is not reflected in the assessment of this person's likeability, trustworthiness, and credibility (wordof-mouth). Therefore, it can be assumed that when the purpose of marketing communication is to create positive brand attitudes, the use of a celebrity endorsement is not justified. It should be noted that a celebrity is a relatively expensive source of communication and may generate conflicting messages when he or she endorses various brands.

3. In the case of celebrity influence on certain elements of the assessment of advertised products, impact was stronger for the watches than for the juice. These results are consistent with the previous research conducted by Friedman and Friedman [1979, pp. 63-71], who indicated that celebrity endorsement brings better results when the advertised products are associated with higher levels of social and psychological risk. An important implication for marketers is that the use of celebrity endorsements is justified only in case of those product categories where physical attractiveness and social status can be transferred onto brand attributes and thus strengthen the brand image.

The research results are consistent with the match-up model (not every product can be advertised by a particular celebrity) and the meaning transfer model (possibility of transferring of elements of the celebrity's image onto selected brand attributes) and, to some extent, with the ELM model (based on the different effects of celebrity endorsement in the case of high and low involvement).

\section{Limitations and Directions of Further Research}

The research conducted was characterised by the limitations. First, the research sample size and structure (sample consisting of students only) do not allow any inferences to be drawn concerning the total population. Second, the way in which respondents were contacted may have influenced the results. That is, the possibly low involvement of some respondents in answering the research questions and the possibility that the advertisements evaluated were displayed improperly. Third, the research results may have been influenced by the wrong choice of product categories (watches and juices) from the point of view of the population studied and types of purchase decisions (degree of consumer involvement). Fourth, the results of the advertised products and endorsers evaluation may be distorted by differences in the evaluation of attractiveness of the celebrity and model.

These limitations suggest directions for further research. One is to perform similar experiments with other socio-demographic groups. The research results presented here 
may also be verified through studying other advertised product groups (including financial services, for which celebrities are routinely used in Poland). Third, endorser categories studied may be expanded to include an expert (in addition to the celebrity and ordinary consumer studied here).

\section{Notes}

1 It was addressed in the first research hypothesis.

2 It is possible that persons who responded to the survey also included individuals who were not students of these schools but visited their social networking service when the research was being conducted.

\section{References}

Abdussalam, P.K. (2014), Celebrity advertisement: key to marketing success, Indian Journal of Commerce and Management Studies, Vol. 5, No. 1, pp. 78-82.

Agrawal, J., Kamakura, W.A. (1995), The economic worth of celebrity endorsers: an event study analysis, Journal of Marketing, Vol. 59, No. 3, pp. 56-62.

Biswas, D., Biswas, A., Das, N. (2006), The differential effects of celebrity and expert endorsements on consumer risk perceptions, Journal of Advertising, Vol. 35, No. 2, pp. 17-31.

Carrillat, F., d'Astous, A., Lazure, J. (2013), For better, for worse? What to do when celebrity endorsements go bad, Journal of Advertising Research, Vol. 53, No. 1, pp. 15-30.

Ding, H., Molchanov, A.E., Stork, P.A. (2011), The value of celebrity endorsements: a stock market perspective, Marketing Letters, Vol. 22, No. 2, pp. 147-163.

Erdogan, B.Z. (1999), Celebrity endorsement: a literature review, Journal of Marketing Management, Vol. 15, No.4, pp. 291-314.

Erdogan, B.Z., Baker, M., Tagg, S. (2001), Selecting celebrity endorsers: the practitioner's perspective, Journal of Advertising Research, Vol. 41, No. 3, pp. 39-48.

Friedman, H.H., Friedman, L. (1979), Endorser effectiveness by product type, Journal of Advertising Research, Vol. 19, No. 5, pp. 63-71.

Green, M.C., Brock, T.C. (2000), The role of transportation in the persuasiveness of public narratives, Journal of Personality And Social Psychology, Vol. 79, No. 5, pp. 701-721.

Green, M.C., Brock, T.C., Kaufman, G.F. (2004), Understanding media enjoyment: the role of transportation into narrative worlds, Communication Theory, Vol. 14, No. 4, pp. 311-327.

Hovland, C., Weiss, W. (1951), The influence of source credibility on communication effectiveness, Public Opinion Quarterly, Vol. 15, No. 4, pp. 635-650.

Hung, K. (2014), Why celebrity sells: a dual entertainment path model of brand endorsement, Journal of Advertising, Vol. 43, No. 2, pp. 155-166. 
Hung, K., Chan, K., Tse, C. (2011), Assessing celebrity endorsement effects in China, Journal of Advertising Research, Vol. 51, No. 4, pp. 608-623.

Kamins, M.A. (1990), An investigation into "match-up" hypothesis in celebrity advertising: When beauty may be only skin deep, Journal of Advertising, Vol. 19, No. 1, pp. 4-13.

Kamins, M.A., Brand, M.J., Hoeke, S.A., Moe, J.C. (1989), Two-sided versus one-sided celebrity endorsements: the impact on advertising effectiveness and credibility, Journal ofAdvertising, Vol. 18, No. 2, pp. 4-11.

Kamins, M.A., Gupta, K. (1994), Congruence between spokesperson and product type: a matchup hypothesis perspective, Psychology \& Marketing, Vol. 11, No. 6, pp. 569-586.

Kahle,L.R., Homer, P.M. (1985), Physical attractiveness of the celebrity endorser: A social adaptation perspective, Journal of Consumer Research, Vol. 11, No. 4, pp. 954-961.

Langmeye, L., Walker, M. (1991), A first step to identify the meaning in celebrity endorsers, Advances in Consumer Research, Vol. 18, No. 1, pp. 364-371.

Lee, J., Thorson, E. (2008), The impact of celebrity-product incongruence on the effectiveness of product endorsement, Journal of Advertising Research, Vol. 48, No. 3, pp. 433-449.

Lord, K., Putrevu, S. (2009), Informational and transformational responses to celebrity endorsements, Journal of Current Issues \& Research in Advertising, Vol. 31, No. 1, pp. 1-13.

Liu, M.T., Chen, Z., Jiang, M. (2007), Influence of endorsers' attractiveness and product match-up toward purchase intentions, International Journal of Business and Management, Vol. 2, No. 2, pp. 3-12.

Lynch, J., Schuler, D. (1994), The matchup effect of spokesperson and product congruency: a schema theory interpretation, Psychology \& Marketing, Vol. 11, No. 5, pp. 417-445.

McCracken, G. (1989), Who is the celebrity endorser? Cultural foundations of the endorsement, Journal of Consumer Research, Vol. 16, No. 3, pp. 310-321.

McGuire, W.J. (1985), Attitudes and attitude change, in: G. Lindzey, E. Aronson, E., (eds.) The Handbook of Social Psychology, Vol. 2, New York: Random, pp. 233-246.

Misra, S., Beatty, S.E. (1990), Celebrity spokesperson and brand congruence, Journal of Business Research, Vol. 21, No. 2, pp. 159-173.

Mittelstaedt, J.D., Riesz, P.C., Burns, W.J. (2000), Why are endorsements effective? Sorting among theories of product and endorser effects, Journal of Current Issues \& Research in Advertising, Vol. 22, No. 1, pp. 55-65.

Norman, G. (2010), Likert scales, levels of measurement and the "laws" of statistics. Advances in Health Sciences Education, Vol. 15, No. 5, pp. 625-632.

Ohanian, R. (1991), The impact of celebrity spokespersons' perceived image on consumers' intention to purchase, Journal of Advertising Research, Vol. 31, No. 1, pp. 46-54.

O’Mahony, S., Meenaghan, T. (1997/1998), The Impact of Celebrity Endorsements on Consumers, Irish Marketing Review, Vol. 10, No. 2, pp. 15-24.

Petty, R.E., Caccioppo, J.T. (1980), Effect of issue involvement on attitudes in an advertising context, in: G.G. Gorn, M.E. Goldberg (eds.), Proceedings of Division 23 Program, American Psychological Association, Montreal, pp. 75-79.

Petty, R.E., Cacioppo, J.T., Schumann, D. (1983), Central and peripheral routes to advertising effectiveness: the moderating role of involvement, Journal of Consumer Research, Vol. 10, No. 2, pp. 135-146,

Petty, R.E., Cacioppo, J.T., Goldman, R. (1981), Personal involvement as a determinant of argument-based persuasion, Journal of Personality and Social Psychology, Vol. 41, No. 5, pp. 847-855.

Raluca, C.A. (2012), Celebrity endorsement strategy, Annals of the „Constantin Brâncuşi” University of Târgu Jiu, Economy Series, Issue 3, pp. 75-79. 
Silvera, D.H., Austad, B. (2004), Factors predicting the effectiveness of celebrity endorsement advertisements, European Journal of Marketing, Vol. 38, No. 11, pp. 1509-1526.

Speck, P.S., Schumann, D.W., Thompson, C. (1988), Celebrity endorsements-scripts, schema and roles: theoretical framework and preliminary tests, in: M.J. Houston (Ed.), Advances in Consumer Research, Vol. 15, pp.68-76.

Spry, A., Pappu, R., Cornwell, T.B. (2011), Celebrity endorsement, brand credibility and brand equity, European Journal of Marketing, Vol. 45, No. 6, pp. 882-909.

Stafford, M., Stafford, T., Day, E. (2002), A contingency approach: the effects of spokesperson type and service type on service advertising perceptions, Journal of Advertising, Vol. 31, No. 2, pp. 17-35.

Till, B.D., Shimp, T.A. (1998), Endorsers in advertising: the case of negative celebrity information, Journal of Advertising, Vol. 27, No. 1, pp. 67-82.

Till, B.D., Busler, M. (2000), The match-up hypothesis: physical attractiveness, expertise, and the role of fit on brand attitude, purchase intent and brand beliefs, Journal of Advertising, Vol. 29, No. 3, pp. 1-13.

Valkenburg, P., van der Voort, T. (1994), Influence of TV on daydreaming and creative imagination: A review of research, Psychological Bulletin, Vol. 116, No. 2, pp. 316-339.

Vorderer, P., Klimmt, C., Ritterfeld, U. (2004), Enjoyment: at the heart of media entertainment, Communication Theory, Vol. 14, No. 4, pp. 388-408.

Weiner, J., Mowen, J.C. (1986), Source credibility: on the independent effects of trust and expertise, in: R.J. Lutz (ed.), Advances in Consumer Research, Vol. 13, pp. 306-310.

Wheeler, R.T. (2009), Nonprofit advertising: impact of celebrity connection, involvement and gender on source credibility and intention to volunteer time or donate money, Journal of Nonprofit \& Public Sector Marketing, Vol. 21, No. 1, pp. 80-107.

Woźniczka, J. (2011), Wykorzystanie tzw. zwykłych ludzi i znanych postaci w kreacji reklamowej a efekty komunikacyjne reklamy, Marketing i Rynek, No. 10, pp. 14-22. 